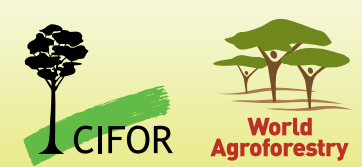

\title{
Enhancing the legal framework towards holistic and sustainable wildlife conservation in Vietnam
}

Pham Thu Thuy, Pham Van Thong, Trinh Thi Mai, Cao Nhat Long, Nguyen Thi Thuy Anh, Nguyen Thi Van Anh, Tang Thi Kim Hong and Nguyen Van Thai

\section{Key messages}

- $\quad$ Biodiversity and wildlife in Vietnam are under increasing pressure from deforestation and illegal wildlife trading.

- A large number of wildlife conservation policies and projects are already in place. However, their effectiveness is hampered by unclear and inconsistent policies; weak law enforcement, monitoring and evaluation; insufficient funding; challenges in achieving the dual goal of conservation and development; environmental and social justice issues; and problems addressing the drivers of deforestation and degradation.

- Despite the persistence of these challenges, Vietnam has new opportunities to address them by moving away from sectoral silos and promoting One Health and landscape approaches; promoting cross-sectoral and cross-border collaboration in addressing the illegal wildlife trade; adopting timely responses to newly emerging issues such as Covid-19 with mixed policy instruments; embedding wildlife conservation policies in green living and consumption behaviour; and tapping into international, regional and national financial initiatives to close finance gaps.

- Sustainable wildlife conservation in Vietnam requires strengthened transboundary and inter-sectoral stakeholder engagement; a holistic and cross-sectoral approach to addressing underlying drivers of deforestation and degradation; sufficient and sustainable funding; and changing consumers' behaviour in buying and using wildlife products.

\section{Introduction}

Vietnam is a biodiversity-rich nation situated in the IndoBurma biodiversity hotspot of Southeast Asia (Dinerstein et al. 2017; Myers et al. 2000). Unfortunately, many of Vietnam's most precious species are directly threatened by unsustainable wildlife farm management, illegal harvesting and international trade (Brooks-Moizer et al. 2009; Janssen and Indenbaum 2019; Challender et al. 2020), deforestation and forest degradation due to agriculture expansion, urbanisation, infrastructure development, population growth and weak forest governance (Tuyet 2001; Nguyen 2017; Van Khuc et al. 2018; Ngo et al. 2020). The country is also a global hub for wildlife trafficking (Nguyen 2003; Grieser-Johns and Thomson 2005; Zhang et al. 2008; Li et al. 2010; Nguyen et al. 2019; De Sadeleer and Godfroid 2020).

Since the 1960s, Vietnam has developed and implemented numerous sectoral and cross-sectoral wildlife management policies to address these problems (Table 1 and Figure 1).
A large number of international wildlife conservation projects have been carried out to strengthen the legal framework, foster cross-sectoral and cross-border collaboration, and empower government agencies, civil society and communities to protect and conserve wildlife (Pham et al. 2018; Trieu and Pham 2020). Despite political commitment and support, there has been a lack of rigorous assessment on the effectiveness of wildlife conservation policies and projects. As the Government of Vietnam is now developing new policies, learning from past initiatives is essential to avoid repeating the same mistakes, as is improving the institutional setting and policy instrument mix to enhance policy outcomes (Schroeder et al. 2020). This infobrief aims to review lessons learned to date, discuss opportunities and challenges for sustainable wildlife management in Vietnam, and propose a future pathway to enhance the effectiveness of wildlife management policies. This paper is built on a review of academic and grey literature, and a national policy dialogue involving around 150 wildlife experts from academic institutions, the private sector, international NGOs, CSOs, donors and the public sector. 
Table 1. Key policies on wildlife conservation and management in Vietnam

\begin{tabular}{|c|c|}
\hline Sectoral policies & Content \\
\hline \multirow{9}{*}{$\begin{array}{l}\text { Terrestrial wildlife } \\
\text { management and the } \\
\text { forestry sector }\end{array}$} & Forestry Law 2017 and Decree 156/2018/NĐ-CP regulating implementation of Forestry Law 2017 \\
\hline & $\begin{array}{l}\text { Decision No. 126/QD-Ttg, Decree } 117 / 2010 / \mathrm{ND}-\mathrm{CP} \text {, Circular No. } 70 / 2007 / \mathrm{TT}-\mathrm{BNN} \text { to relax resource-use } \\
\text { restrictions and promote community forest protection for poverty reduction }\end{array}$ \\
\hline & $\begin{array}{l}\text { Decree 06/2019/ND-CP refined by Decree 84/2021/ND-CP on Management of Endangered, Precious } \\
\text { Flora and Fauna and CITES Enforcement }\end{array}$ \\
\hline & $\begin{array}{l}\text { Decree } 160 / 2013 / \mathrm{ND}-\mathrm{CP} \text { amended by Decree } 64 / 2019 / \mathrm{ND}-\mathrm{CP} \text { on Criteria for Identification and } \\
\text { Management of Endangered, Precious and Rare Species Prioritized for Protection }\end{array}$ \\
\hline & Decree No. 35/2019/NĐ-CP stipulating penalties for forestry violations \\
\hline & Penal Code 2015 amended in 2017 regulates protection of endangered, precious and rare animals \\
\hline & $\begin{array}{l}\text { Prime ministerial decisions on conservation programmes and strategies for species such as elephants, } \\
\text { tigers and primates, and proposed decisions for species such as pangolins }\end{array}$ \\
\hline & Decree 01/2019/NĐ-CP on Rangers' Functions and Responsibilities \\
\hline & National Forestry Strategy 2021-2030, with Vision for 2050 \\
\hline \multirow{4}{*}{$\begin{array}{l}\text { Biodiversity } \\
\text { conservation }\end{array}$} & National Biodiversity Strategy 2013-2020, with Vision for 2030 \\
\hline & Biodiversity Law 2008 \\
\hline & Decree 65/2010/NĐ-CP on Implementation of Biodiversity Law 2008 \\
\hline & $\begin{array}{l}\text { Decree } 160 / 2013 / \mathrm{ND}-\mathrm{CP} \text { on Criteria for Identification and Management of Endangered, Precious and } \\
\text { Rare Species Prioritized for Protection }\end{array}$ \\
\hline \multirow{6}{*}{$\begin{array}{l}\text { Fisheries and aquatic } \\
\text { policies }\end{array}$} & Fisheries Law 2017 \\
\hline & Decree 26/2019/NĐ-CP on Guideline for Implementation of the Fisheries Law \\
\hline & Decree 42/2019/NĐ-CP on Sanctions for Administrative Violations in the Fisheries Sector \\
\hline & Article 242 of the 2015 Penal Code, amended in 2017, on the crime of destroying aquatic resources \\
\hline & $\begin{array}{l}\text { Resolution No. 36-NQ/TW on Sustainable Development of Vietnam's Marine Economy to 2030, with } \\
\text { Vision for } 2045\end{array}$ \\
\hline & $\begin{array}{l}\text { Decision No. 811/QD-BNN-TCTS approving the Vietnam Sea Turtle Conservation Action Plan 2016- } \\
2025\end{array}$ \\
\hline \multirow[t]{2}{*}{ Wildlife and livestock } & Veterinary Law 2015 \\
\hline & Livestock Law 2018 \\
\hline \multirow[t]{3}{*}{ Trade policies } & The Advertisement Law prohibits wildlife trade advertisements on any advertising platform \\
\hline & Foreign Trade Management Law 2017 \\
\hline & Investment Law 2020 includes a list of wildlife for which business investment activities are prohibited \\
\hline \multirow{2}{*}{$\begin{array}{l}\text { Other directives/ } \\
\text { decisions }\end{array}$} & Directive No. 29/CT-TTg on Urgent Solutions for Wildlife Management in 2020 \\
\hline & Decision No. 2713/QD-BNN-TCLN promulgating the ivory and rhino horn action plan for 2018-2020 \\
\hline Tourism & $\begin{array}{l}\text { Under Environment Protection Law } 2020 \text { and Forestry Law 2017, PFES includes the role of tourism in } \\
\text { financing wildlife conservation }\end{array}$ \\
\hline $\begin{array}{l}\text { Wildlife violations in } \\
\text { criminal law }\end{array}$ & $\begin{array}{l}\text { Article } 244 \text { of the } 2017 \text { amendment to Penal Code } 2015 \text { and administrative sanctions under Decree } \\
\text { 35/2019/NĐ-CP on the Forestry Sector and Decree 42/2019/ND-CP on the Fisheries Sector }\end{array}$ \\
\hline $\begin{array}{l}\text { Health and zoonotic } \\
\text { diseases }\end{array}$ & $\begin{array}{l}\text { Since the Covid-19 pandemic, the Prime Minister signed Directive 29/2020/CT-TTg on Urgent } \\
\text { Solutions for Wildlife Management }\end{array}$ \\
\hline
\end{tabular}




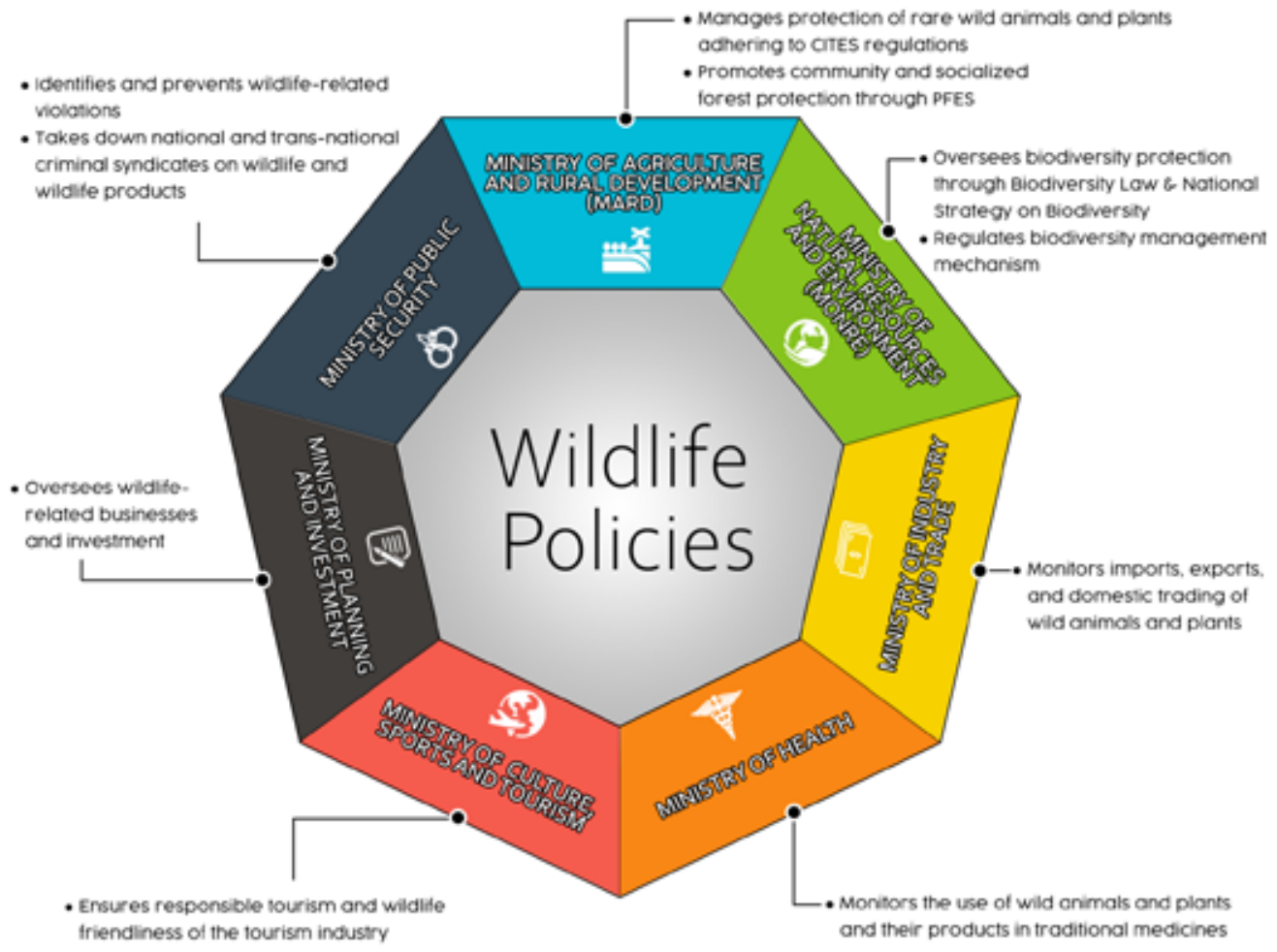

Figure 1. Institutional setting for wildlife conservation in Vietnam

Source: Data compiled by the authors (2021)

\section{Opportunities for sustainable wildlife management in Vietnam}

With a strong political commitment towards sustainable wildlife management, the Government of Vietnam has actively taken part in international treaties such as CBD and CITES and in combating the regional illegal wildlife trade. These initiatives have laid the legal foundation for Vietnam to enhance its wildlife conservation policies.

\section{Moving away from sectoral silos, promoting} cross-sectoral and cross-border approaches, and strengthening law enforcement: Figure 1 and Table 1 show Vietnam wildlife conservation policies aim to promote cross-sectoral and regional cooperation to address complex drivers of biodiversity loss and unsustainable wildlife management (NFGA 2016; WCS 2016; Jiao et al. 2021). By signing up to and promoting the One Health approach, the country has shown its strong commitment to transformational change in tackling the complexities of intersecting health, biodiversity and socioeconomic factors (Harrison et al. 2019; Nguyen 2021). As an immediate response to COVID-19, Vietnam has been lauded as a pioneer (along with China, Korea, Bolivia, and Gabon) in strengthening the legal framework on wildlife trading (Amal et al. 2020; Booth et al. 2021). Vietnam has also established

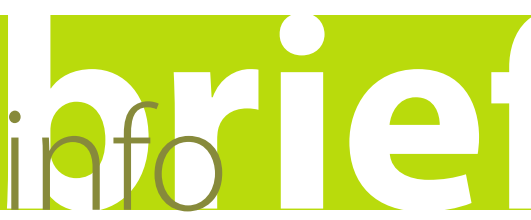


sources such as green bonds and forest securities, and mobilizing private sector finance for wildlife conservation policies and measures. International NGO representatives participating in our policy dialogue further highlighted that in response to Covid-19 and to avoid future pandemics, international donors are dedicating more funding to wildlife research, which could help to strengthen biodiversity monitoring and evaluation in Vietnam.

\section{Changing consumption patterns: Younger generations} have greener consumption preferences and their diets are moving away from animal-based products (Pham et al. 2020). Policy dialogue participants also saw Covid-19 as a wakeup call for many Vietnamese people, while increasing numbers of reports are documenting public support for closing down wildlife markets. These lifestyle changes and increasing awareness of human-ecosystem-animal interactions provide the enabling conditions for sustainable wildlife management.

\section{Challenges: Moving from policy to practice}

Although policy dialogue participants were fully aware of government efforts and opportunities to strengthen wildlife conservation, translating policies and commitments into practice remains difficult, with challenges including:

Weak legal framework: Despite a large number of policies on wildlife conservation being issued, their implementation on the ground has been impeded by overlapping institutional frameworks, inadequate enforcement of existing environmental laws, non-standard implementation of environmental impact assessments, insufficient regulation of protected forests, ineffective border control strategies to prevent illegal trade, and a lack of stakeholder participation in wildlife conservation decision making (MONRE 2019; World Bank 2019). Overlapping and inconsistent guidelines have created major challenges for local authorities in conserving wildlife. For example, the Ministry of Agriculture and Rural Development (MARD) has issued lists of endangered species under Decree 84/2021/ ND-CP and Decree 26/2019/NO-CP, while MONRE has its own list under Decree 64/2019/ND-CP. Meanwhile, the Investment Law issued by the National Assembly has a different protected wildlife list of its own. Moreover, Decree 84/2021/ND-CP and Decree 64/2019/NĐ-CP focus purely on rare, precious species while lacking provisions to protect more common species (e.g., certain birds), which suffer from intensive hunting (Pannature 2021). Stakeholders participating in the policy dialogue also pointed out challenges arising when policies only focus on conserving wildlife in protected areas, whereas many endangered species proliferate in or migrate to and from unprotected areas. The policy dialogue participants also highlighted a lack of adequate attention to confiscation regulation,conflict of policy, bio-security, and disease control and the high transaction cost in tracking species origin. For example, Decree 29/2018/ND-CP stipulates that as public property, wildlife is subject to complex bureaucratic procedures that have led to delays in providing timely rescues and releasing confiscated animals. Policy dialogue participants also stressed that current penalties are either too low or are difficult to enforce. Inconsistencies between provisions in the Penal Code and Decree 35/2019/NĐ-CP on poaching, trading and transporting illegal wildlife also pose challenges to putting wildlife policies into practice.

Under-funded and under-staffed sectors: Financial and technical norms for animal rescue and biodiversity conservation are lacking compared to other sectors. Pham et al. (2018) found that in many provinces, available funds are sufficient to meet only $40 \%$ of provincial requirements for implementing forest conservation. To date, only 39\% of national parks and $21 \%$ of protected areas receive income from PFES, while just $6 \%$ of protected areas receive over VND 10 billion annually. Meanwhile, 31\% of national parks and $15 \%$ of protected areas receive less than VND 500 million a year (Pham et al. 2018a). Covid-19 has also had a significant impact on funds as the government has prioritized responses to the pandemic. Post-Covid economic and social development recovery strategies will also pose challenges to ensuring sufficient funding for wildlife conservation (Pham et al. 2018b; BCA 2021). While providing financial and social incentives for actors to move away from unsustainable practices and engage in wildlife conservation is crucial for conservation outcomes, all policy dialogue participants highlighted a lack of financial incentives for behavioral changes. Total revenues from the illegal wildlife trade in Vietnam are eight times higher than expenditure on monitoring and enforcement, two times higher than the total budget for Forest Protection Department (FPD) staff, and four times higher than the total amount collected in fines each year (Nguyen 2002). FPD staff salaries, which range from USD 200 to USD 450 per month, provide little incentive for recruiting additional human resources. Meanwhile, rangers are responsible for 1,000 to 1,500 ha of forest (Nguyen et al. 2019). Government representatives participating in the policy dialogue said there has been a marked drop in the number of forest rangers in national parks and protected areas as a result of Decree 01/2019/ NĐ-CP. This will pose a significant challenge to biodiversity protection in the future.

Unsustainable wildlife farms: In Vietnam, farms involved in the commercial breeding of wildlife species are obliged to use parent stock bred in captivity, but farm 
owners continue to purchase wild founder stock and wild individuals (Brooks et al. 2010; You 2020). Farms breeding protected species listed under Group IB in Decree 06/2019/ NĐ-CP as amended by Decree 84/2021/NĐ-CP are required to register with CITES Vietnam, while those breeding Group IIB species need to register with provincial FPDs. Meanwhile, those farming unlisted species should report to district FPDs. However, according to policy dialogue participants, sourcing and slaughtering of wild-caught animals is widespread as there are weaknesses in how numbers are recorded in the monitoring process. In addition, a lack of consistent and detailed guidelines on standards for husbandry, enclosures and biosecurity makes wildlife farm management more difficult, posing potential health risks to the public. Experts participating in the policy dialogue frequently cited corruption and weak law enforcement as being major obstacles to sustainable and effective captive breeding management. According to policy dialogue participants, another major obstacle to sustainable wildlife management is the absence of regulations on animal welfare in Vietnam.

\section{Weak monitoring, reporting and verification: Data} on biodiversity status, offline and online legal and illegal wildlife trading in Vietnam is scarce, and not up to date (Giles et al. 2006; Van et al. 2019; Pham et al. 2021). Wildlife crime is underreported, and either fails to capture the large numbers of wild species being caught and traded (Yiming and Dianmo 1998), or only reflects part of a complex wildlife value chain (OECD 2019; Jiao et al. 2021). Monitoring and law enforcement in Vietnam is also seen as ineffective due to overlapping policies, a lack of resources for enforcement, ineffective and inefficient cross-regional and cross-sectoral collaboration, elite capture and corruption (Nguyen et al. 2019).

Conservation versus development: While conservation agencies promote expansion and strengthening of national parks, protected areas and special use forests to improve wildlife protection (ICEM 2003), there is significant kickback from national and international actors against new widespread prohibitions (Thuan 2005). Some actors point to the ethics of removing impoverished communities from newly established protected areas where they have resided for generations and which they rely on for their livelihoods. Many provincial governments also cite poverty as a significant obstacle to wildlife conservation (Nguyen et al. 2019). In Northern Vietnam, where Covid-19 has affected incomes and food availability, local people have had to resort to forest exploitation, including poaching and consuming wildlife, for earnings and food (Pham et al. 2021a). In Southern Vietnam, evidence to date shows that in many provinces, local households see expanding wildlife farms as a post-Covid recovery and poverty reduction strategy (Pham et al. 2021c). While the conservation community advocates banning wildlife farms as an immediate response to Covid-19, the fact that households in many provinces depend on wildlife farming as their main source of income creates major challenges for wildlife conservation and management (Pham et al. 2021).

Limited technical capacity: Policy dialogue participants highlighted the limited knowledge and capacity of government agencies - notably the police, customs officers and local rangers - with regard to species identification, wildlife management, confiscation and zoonotic diseases. Trieu and Pham (2020) also highlight the weak forestry education system in Vietnam, which fails to equip students with adequate skills and knowledge to implement sustainable forest management, including wildlife conservation. Moreover, while PFES aims to increase forest cover and forest quality, including conserving biodiversity and wildlife, provincial governments lack the technical capacity and funding necessary for assessing and monitoring forest quality, including wildlife conservation (Pham et al. 2013, 2021d).

\section{The way forward}

Mixed policy instruments are required: The conservation community currently advocates regulatory approaches such as closing wildlife markets to achieve effective wildlife conservation. However, such bans have proven ineffective in other countries, can drive demand underground to black markets (Miron and Zwiebel 1995), and create ethical quandaries because poor communities rely on such resources for survival (Biggs et al. 2017). Outright bans on wildlife trading should be carefully designed, and aside from threatened species, should focus on bird and mammal species that pose elevated risks of emerging infectious diseases (EIDs) and dangers to public health (Chris 2020). Establishing a working list of high-risk EID species; creating and modernizing a national database registry for wildlife farms; applying mandatory (cost effective) microchipping of registered animals for ease of identification; and establishing formal regulations for animal health, welfare and disease prevention might help to reduce from the risk of zoonotic disease outbreaks, prevent farms supplementing their livestock with illegally caught wildlife, and remove a demand avenue for the poachers who supply them. Complements to regulatory approaches, such as changing consumer preferences for wildlife products, diversifying local livelihoods, pursuing sustainable conservation finance, ecological fiscal transfers, and promoting pervasive educational and social marketing measures about wildlife usage, are critical for driving change across civil societies (Wilkie et al. 2016; Dobson et al. 2020; Pham et al. 2021). Economic regulatory measures, such as increasing penalties, 
taxes and wildlife trade quotas, would also help (Nguyen et al. 2019). In an increasingly risk-averse society, public perception of wildlife diseases may hamper support for biodiversity conservation (Buttke et al. 2015). Therefore, individual advocacy and awareness (e.g., environmental and conservation education) have to play an important role (Sleeman et al. 2019). As forests are home to wildlife, without maintaining forests the survival of wild animals is put at risk. Focusing only on the protection of individual species without addressing the root causes of problems forest destruction, fragmentation and degradation - will not lead to effective wildlife conservation policies. While technical and financial efforts are put towards species conservation, addressing the drivers of deforestation and degradation, which are often rooted in national development goals (e.g., infrastructure development, expansion of agriculture and aquaculture (Van Khuc et al. 2018; Pham et al. 2012, 2019), is essential for ensuring the long-term preservation of biodiversity into the future.

\section{Carbon versus biodiversity conservation: COP 26 and} the Paris Agreement highlight the important role of forests in providing carbon sequestration services. However, there are concerns that emissions reduction projects may fail to deliver biodiversity co-benefits if they focus only on high carbon stock areas. If carbon focused projects are not properly planned, they could negatively affect biodiversity by diverting funds for conservation away from high-biodiversity areas with lower carbon stocks (Murray and Jones 2014). Harmonizing carbon and biodiversity objectives is essential for ensuring sustainable forestry ecosystems (Paoli et al. 2010). Any carbon policies or projects should adopt biodiversity-friendly methods, such as spatial targeting of REDD+ interventions (Jantz et al. 2014; Venter 2014); provide supplementary financing with a biodiversity delivery focus, such as wildlife premiums or conservation funds (Dinerstein et al. 2017); and bundle payments for multiple ecosystem services. Meanwhile, biodiversity-specific management strategies, such as biodiversity conservation, should be factored into forest plantation designs, with optimum rotation ages applied to maximize joint value from timber production and carbon sequestration (Phelps et al. 2012; Martin et al. 2013; Nghiem 2014). All such measures should adopt a landscape management approach. In addition, capacity building, technology transfer and financial support are required to reduce deforestation and conserve biodiversity in an efficient manner to enable win-win carbon and biodiversity solutions (Lokesh 2018).

The One Health approach: To address threats to the long-term future of biodiversity, a more interdisciplinary approach to problems is required that combines the research expertise of ecologists, conservation biologists, veterinarians, epidemiologists, cultural and social scientists, and human health professionals (Bell et al. 2004). The social science aspect of biodiversity conservation should be emphasized along with its natural science aspect for the One Health approach to function effectively. A major driver of EIDs and pandemic potential is human-wildlife interaction (Jones et al. 2008; Shivaprakash 2021). Therefore, to avoid future pandemics in Vietnam (Huong et al. 2020), the One Health approach needs to tackle the paradoxes of pandemic prevention, climate change, economic growth and poverty reduction (Archarya 2019; Pham and Riedel 2019). Research on wildlife trading, wildlife monitoring and creating a national biodiversity database are all essential (Li 2001), and emphasis should be placed on veterinary science for wild animals, which currently receive disproportionate attention, funding and manpower compared to domestic animals, while being equally important (Buttke et al. 2015).

\section{Wildlife conservation policies need to be coupled with environmental and social justice: As Vietnam's Forestry} Development Strategy 2006-2020 failed to reduce the number of poor households in forested areas (Trieu et al. 2020), an average income target has been set for ethnic minority people working in forestry at more than twice the 2020 level by 2025 (GSRV 2021). While the wildlife trade poses a significant threat to biodiversity, the consumption of wild animals is another important threat in Vietnam (Booth et al. 2021; Pham et al. 2021). Conservation policies that fail to incorporate social and environmental justice are never implemented properly on the ground, so it is vital to ensure local livelihoods and biodiversity conservation needs go hand in hand. The questions of who controls, who is blamed and who benefits should also receive adequate attention. Local people are frequently blamed as being drivers of biodiversity loss and key actors in illegal wildlife trading, but this narrative overlooks the fact that these illegal acts are organized by illegal large-scale global, regional and national cross-border wildlife traders who recruit poachers from indigenous communities to trap the wildlife they trade (Nguyen et al. 2019). The narratives for problems and solutions to wildlife conservation need to change and move away from blaming specific and often disadvantaged groups to addressing all actors involved in wildlife trade value chains. Moreover, wildlife trading is highly gender-divided, and overlooking the gender dimensions of producers, traders, and consumers of wildlife products prevents both policymakers and practitioners from seeing particular problems and potential sustainable solutions that have a basis in gender divisions (McElwee 2012).

\section{Sustainable financing for biodiversity conservation:}

There are several financial mechanisms, such as PFES and REDD+, supporting local livelihoods with the aim of 
reducing poverty. However, these alone are not enough, and complying with results-based payment schemes can be costly, particularly in ensuring social safeguards standards and setting up proper monitoring, reporting and verification systems (Pham et al. 2012, 2019). While the government is exploring financial options, such as biodiversity credits, debt for nature conservation swaps, green bonds and green credits to support conservation and local livelihoods, strengthening forest and land tenure security is essential for enabling local communities to participate in such initiatives (Pham et al. 2012), as is the need to ensure equitable, fair and transparent benefitsharing mechanisms (Pham et al. 2018, 2019). Using both cash and non-cash incentives for regulators, rangers and informants to intensify efforts against illegal wildlife trading can also help in ensuring effective implementation of wildlife conservation policies and projects (Daan 2019; Nguyen et al. 2019).

\section{Conclusion}

This infobrief discusses both opportunities and challenges for sustainable wildlife management in Vietnam. Our study shows that despite the large number of wildlife conservation policies and projects in Vietnam, unclear and inconsistent policies; weak law enforcement, monitoring and evaluation; insufficient funding; challenges in achieving the dual goal of conservation and development; and environmental and social injustices in addressing the drivers of deforestation and degradation have all impeded the implementation of these policies on the ground. However, Vietnam can address these barriers by moving away from sectoral silos and promoting One Health and landscape approaches; promoting crosssectoral and cross-border collaboration in addressing the illegal wildlife trade; adopting timely responses to newly emerging issues such as Covid-19 with mixed policy instruments; embedding wildlife conservation policies in green living and consumption behaviour; and tapping into international, regional and national financial initiatives to close finance gaps.

\section{Acknowledgements}

This study was funded by the COVID-19 Hub, the CGIAR Research Program on Forests, Trees and Agroforestry (FTA), the United States Agency for International Development (USAID) and the International Food Policy Research Institute (IFPRI). We would like to express our special thanks to Russell J. Gray from Save Vietnam's Wildlife and all the experts participating in the national policy dialogue on "Assessing the effectiveness of wildlife conservation policies, lessons learned and recommendations in the period 2021-2030, with a vision to 2050", on 13 October 2021.

\section{References}

Amaël B, McNeely J, Magellan K, Miller JRB, Porter L, Dutta T, Kadinjappalli KP, Sharma S, Shahabbudin G, Fikty A, Ryan GE, Hughes A, Mutalib AHA, Ahmad ZAW, Damber B, Chavanich SA, Ju LC, Gale GA, Ghaffari H, Ghimerey Y, Vijaya KJ, Khatiwada AP, Khatiwada M, Murali K, Ngwe L, Paudel PK, Sadykova C, Savini T, Bharat BS, Strine CT, Sutthacheep M, Ee PW, Yeemin T, Zahirudin NZ, Li Z. 2020. COVID-19 highlights the need for more effective wildlife trade legislation. Trends in Ecology \& Evolution 35 (12): 1052-1055.

Acharya, S. (2019). Trafficking of wildlife: An emerging problem in South Asia. Global Journal of Human-Social Science: Economics 19(5).

BCA (Biodiversity Conservation Agency). 2021. Báo cáo đánh giá nhu cầu và xây dựng kế hoạch tập huấn nhằm tăng cường năng lực thực hiện các quy định của pháp luật về quản lý, bảo vệ đa dạng sinh học và động vật hoang dã cho các bên liên quan (in Vietnamese).

Bell D, Roberton S and Hunter PR. 2004. Animal origins of SARS coronavirus: Possible links with the international trade in small carnivores. Royal Society 359 (1447).

Biggs D, Holden MH, Braczkowski A, Cook CN, Milner-Gulland EJ, Phelps J and Possingham HP. 2017. Breaking the deadlock on ivory. Science 358(6369): 1378-1381.

Booth $\mathrm{H}$, Arias M, Brittain S, Challender D, Khanyari M, Kuiper T, Li Y, Olmedo A, Oyanedel R, Pienkowski T and MilnerGulland EJ. 2021. Saving lives, protecting livelihoods, and safeguarding nature: Risk-based wildlife trade policy for sustainable development outcomes post-COVID-19. Front. Ecol. Evol.

Brooks EGE, Roberton SI and Bell DJ. 2010. The conservation impact of commercial wildlife farming of porcupines in Vietnam. Biol. Conserv. 143: 2808-2814. 10.1016/j. biocon.2010.07.030

Brooks-Moizer F, Roberton, SI, Edmunds K and Bell D. 2009. Avian influenza H5N1 and the wild bird trade in Hanoi, Vietnam. Ecology and Society 14(1).

Buttke DE, Decker DJ and Wild MA. 2015. The role of one health in wildlife conservation: A challenge and opportunity. Journal of Wildlife Diseases 51(1): 1-8.

Chris W. 2020. COVID-19 and the curse of piecemeal perspectives. Front. Vet. Sci. https://doi.org/10.3389/ fvets.2020.582983

Challender DW, Heinrich S, Shepherd CR and Katsis LK. 2020. International trade and trafficking in pangolins, 1900-2019. In Pangolins (pp. 259-276). Academic Press.

Daan PU. 2019. Chinese wildlife trafficking networks along the Silk Road. In Organized Crime and Corruption Across Borders: pp. 114-133. DOI:10.4324/9780429031045-7

De Sadeleer N and Godfroid J. 2020. The story behind COVID19: Animal diseases at the crossroads of wildlife, livestock and human health. European Journal of Risk Regulation 11(2): 210-227. doi:10.1017/err.2020.45 
Dinerstein E, Olson D, Joshi A, Vynne C, Burgess ND, Wikramanayake E and Saleem M. 2017. An ecoregionbased approach to protecting half the terrestrial realm. BioScience 67(6): 534-545.

Dobson AP, Pimm SL, Hannah L, Kaufman L, Ahumada JA, Ando AW et al. 2020. Ecology and economics for pandemic prevention. Science 369:379-81. doi: 10.1126/ science.abc3189

Giles BG, Ky TS, Do HH and Vincent ACJ. 2006. The catch and trade of seahorses in Vietnam. In Hawksworth DL and Bull AT. eds. Human Exploitation and Biodiversity Conservation. Topics in Biodiversity and Conservation 3. Dordrecht, Netherlands: Springer. https://doi. org/10.1007/978-1-4020-5283-5_10

Grieser-Johns A and Thomson J. 2005. Going, going, gone: The illegal trade in wildlife in East and Southeast Asia. Washington, DC: World Bank.

GSRV (The Government of Socialist Republic of Vietnam). 2020. Directive No. 29/CT-TTg on a Number of Urgent Solutions for Wildlife Management. Vietnam. Available online at: https://english.luatvietnam.vn/chinh-sach/chithi-29-ct-ttg-2020-giai-phap-cap-bach-quan-ly-dong-vathoang-da-187252-d1.html (accessed 12 January 2021).

GSRV (The Government of Socialist Republic of Vietnam). 2021. Decision 523/QD-TTg 2021 approving the forestry development strategy for the 2021-2030 period. Available online at: https://english.luatvietnam.vn/decision-no523-qd-ttg-dated-april-01-2021-of-the-prime-ministerapproving-vietnams-forestry-development-strategy-forthe-2021-2030-period-with-a-200559-Doc1.html (accessed 12 January 2021).

Harrison S, Kivuti-Bitok L, Macmillan A and Priest P. 2019. EcoHealth and one health: $A$ theory-focused review in response to calls for convergence. Environment International 132 (105058): 1-15

Huong NQ, Nga NTT, Long NV, Luu BD, Latinne A, Pruvot $\mathrm{M}$ and Olson SH. 2020. Coronavirus testing indicates transmission risk increases along wildlife supply chains for human consumption in Viet Nam, 2013-2014. PloS one 15(8): e0237129.

ICEM. 2003. Vietnam national report on protected areas and development. Review of Protected Areas and Development in the Lower Mekong River Region. International Centre for Environmental Management, Australia. http://www.mekongprotected-areas. org/vietnam/docs/vietnam-pad.pdf (accessed 26 October 2021).

Janssen J and Indenbaum RA. 2019. Endemic Vietnamese reptiles in commercial trade. Journal of Asia-Pacific Biodiversity 12(1): 45-48.

Jantz P, Goetz S and Laporte N. 2014. Carbon stock corridors to mitigate climate change and promote biodiversity in the tropics. Nature Climate Change 4:138-142.
Jiao Y, Yeophantong P and Lee TM. Strengthening international legal cooperation to combat the illegal wildlife trade between Southeast Asia and China. Front. Ecol. Evol. https://doi.org/10.3389/fevo.2021.645427

Jones KE, Patel NG, Levy MA, Storeygard A, Balk D, Gittleman $J L$ and Daszak P. 2008. Global trends in emerging infectious diseases. Nature 451(7181): 990-993.

Li YM. 2001. Advances in game hunting, wildlife trade and hunting sustainability. Biodiv Sci 9(4): 414-421. DOI: 10.17520/biods.2001061

Li YB, Wei ZY, Zou Y, Fan DY and Xie JF. 2010. Survey of illegal smuggles of wildlife in Guangxi. Chin. J. Wildlife 31: 280-284.

Lokesh CD. 2018. Conserving carbon and biodiversity through REDD+ implementation in tropical countries. Climate Change, Food Security and Natural Resource Management: 281-297. DOI: 10.1007/978-3-31997091-2_15.

[MARD] The Ministry of Agriculture and Rural Development. 2016. Quyết định số 3158/QĐ-BNN-TCLN: Công bố hiện trạng rừng năm 2015 (In Vietnamese).

Martin PA, Newton AC and Bullock JM. 2013. Carbon pools recover more quickly than plant biodiversity in tropical secondary forests. Proceedings of the Royal Society: Biological Sciences 280:20132236.

McElwee PD. 2012. The gender dimensions of the illegal trade in wildlife: Local and global connections in Vietnam. ResearchGate. https://www.researchgate.net/ publication/287883523_The_gender_dimensions_of_the_ illegal_trade_in_wildlife_Local_and_global_connections_ in_Vietnam

Miron JA and Zwiebel J. 1995. The economic case against drug prohibition. J. Econ. Perspect. 9: 175-192.

MONRE. 2019. The sixth national report to the United Nations Convention on Biological Diversity.

Murray JP and Jones JPG. 2014. Safeguarding biodiversity in REDD+: Necessary but not sufficient to help slow global biodiversity loss. REDD+ Safeguards Brief 5. https://www. cifor.org/publications/pdf_files/SafeguardBrief/5193brief.pdf

Myers N, Mittermeier RA, Mittermeier CG, Da Fonseca GA and Kent J. 2000. Biodiversity hotspots for conservation priorities. Nature 403(6772): 853-858.

NFGA. 2016. China-Vietnam training seminar held in Guilin recently. Beijing: China Forestry Publishing.

Ngo DT, Le AV, Le HT, Stas SM, Le TC, Tran, HD and Spracklen DV. 2020. The potential for REDD+ to reduce forest degradation in Vietnam. Environmental Research Letters 15(7), 074025.

Nguyen, MN. 2017. Urban population in Vietnam 20152020. Statista. Retrieved from https://www.statista.com/ statistics/603397/vietnam-urban-population/

Nguyen VS, Vu NH, Dinh VT, Thai VH, Nguyen TMP, Thai TKO, Vuong TKH and Nguyen TT. 2019. Vietnam, the big market 
and cross bridges of illegal wildlife trade in Asia: Causes and solutions. AgBioForum 21(3): 35-47.

Nguyen VS. 2002. Illegal trading of wildlife species and cost of enforcement and monitoring in Vietnam. University Library, University of the Philippines at Los Baños.

Nguyen VS. 2003. Wildlife trading in Vietnam: why it flourishes. Singapore: EEPSEA.

Nghiem N. 2014. Optimal rotation age for carbon sequestration and biodiversity conservation in Vietnam. Forest Policy and Economics 38: 56-64.

Nguyen T. 2021. Signing Ceremony of Viet Nam One Health Partnership Framework for Zoonoses, phase 2021-2025. WCS Vietnam.

OECD. 2019. The illegal wildlife trade in Southeast Asia: Institutional capacities in Indonesia, Singapore, Thailand and Vietnam. Paris: OECD Publishing, doi: 10.1787/14fe3297-en

Paoli GD, Wells PL, Meijaard E, Struebif MJ, Marshall AJ, Obidzinski K, Tan A, Rafiastanto A, Yaap B, Slik JWF, Morel A, Perumal B, Wielaard N, Husson S and D'Arcy L. 2010. Biodiversity Conservation in the REDD. Carbon Balance and Management 5(7). https://doi.org/10.1186/1750-0680-5-7

Pannature. 2021. Địa ngục chim trời: Dẹp hoài không nổi?! Trung tâm Con người và Thiên nhiên. https://nature.org. vn/vn/2021/04/dia-nguc-chim-troi-dep-hoai-khong-noi/ (in Vietnamese).

Pham TT, Moeliono M, Nguyen TH, Nguyen HT, Vu TH. 2012. The context of REDD+ in Vietnam: Drivers, agents and institutions. Occasional Paper 75. Bogor, Indonesia: CIFOR.

Pham TH and Riedel J. 2019. Impacts of the sectoral composition of growth on poverty reduction in Vietnam. Journal of Economics and Development.

Pham TT, Dao TLC, Hoang TL, Bui TMN, Pham HL and Nguyen VD. 2018. Opportunities and challenges in mobilizing finance to implement Vietnam's Forestry Development Strategy for 2006-2020. Occasional Paper 190. Bogor, Indonesia: CIFOR.

Pham TT, Bui TMN, Dao TLC, Hoang TL, Pham HL, Nguyen VD. 2018a. The role of payment for forest environmental services (PFES) in financing the forestry sector in Vietnam. Bogor, Indonesia: CIFOR.

Pham TT, Bui TMN, Pham HL and Nguyen VD. 2018b. The potential of REDD+ to finance forestry sector in Vietnam. Bogor, Indonesia: CIFOR.

Pham TT, Duong TBN and Hoang TL. 2021b. COVID impacts in Son La. Technical report, Bogor, Indonesia: CIFOR.

Pham TT, Tang TBH, Dang HP, Nguyen TKN and Hoang TL. 2021c. COVID impacts on wildlife farms in Southern Vietnam. Technical Report. Bogor, Indonesia: CIFOR.

Pham TT, Bennett K, Vu TP, Brunner J, Le ND and Nguyen DT. 2013. Payments for forest environmental services in Vietnam: from policy to practice. Brief 22. Bogor, Indonesia: CIFOR.
Pham TT, Nguyen TD, Dao CTL, Hoang LT, Pham LH, Nguyen LT and Tran BK. 2021. Impacts of payment for forest environmental services in Cat Tien National Park. Forests 12: 921. https:// doi.org/10.3390/f12070921

Pham TT, Hoang TL, Nguyen DT, Dao TLC, Ngo HC and Pham VH. 2019. The context of REDD+ in Vietnam: Drivers, agents and institutions. 2nd edition. Occasional Paper 196. Bogor, Indonesia: CIFOR.

Phạm TT, Ngô HC, Hoàng MH, Williams $P$, Hoàng TL and Đào TLC. 2020. Chiến lược và chính sách phát triển lâm nghiệp thế giới: Định hướng của 53 quốc gia. Báo cáo chuyên đề 261. Bogor, Indonesia: CIFOR.

Pham TT, Tran YL, Tang TKH, Dang HP. 2021. The economic value of the wildlife trade in Vietnam. Infobrief. Bogor, Indonesia: CIFOR.

Phelps J, Webb EL and Adams WM. 2012. Biodiversity co-benefits of policies to reduce forest-carbon emissions. Nature Climate Change 2: 497-503.

Shivaprakash KN, Sen S, Paul S, Kiesecker JM and Bawa KS. 2021. Mammals, wildlife trade, and the next global pandemic. Current Biology 31(16): 3671-3677.

Sleeman JM, Richgels KLD, White CL and Stephen C. 2019. Integration of wildlife and environmental health into a One Health approach. Revue Scientifique et Technique (International Office of Epizootics) 38(1): 91-102.

Schroeder H, Di Gregorio M, Brockhaus M and Pham TT. 2020. Policy learning in REDD+ donor countries: Norway, Germany, and the UK. Global Environmental Change 63: 102-106.

Thuan DD. 2005. Forestry, poverty reduction and rural livelihoods in Vietnam. Hanoi: Labour and Social Affairs Publishing House.

Trieu VH, Pham TT and Dao TLC. 2020. Vietnam Forestry Development Strategy: Implementation results for 20062020 and recommendations for the 2021-2030 strategy. Occasional Paper 213. Bogor, Indonesia: CIFOR.

Tuyet D. 2001. Characteristics of karst ecosystems of Vietnam and their vulnerability to human impact. Acta Geologica Sinica-English Edition 75(3): 325-329.

Van Khuc Q, Tran BQ, Meyfroidt P and Paschke MW. 2018. Drivers of deforestation and forest degradation in Vietnam: An exploratory analysis at the national level. Forest Policy and Economics 90: 128-141.

Van TP, Luu VQ, Tien TV, Leprince B, Khanh LTT and Luiselli L. 2019. Longitudinal monitoring of turtle trade through Facebook in Vietnam. Herpetological Journal 29(1).

Venter O. 2014. REDD+ policy: Corridors of carbon and biodiversity. Nature Climate Change 4: 91-92

[WCS] Wildlife Conservation Society. 2016. Laos, China and Vietnam enhance cooperation to combat transnational wildlife trafficking networks. Bengaluru: WCS.

World Bank. 2019. Forest Country Note - Vietnam. Washington, DC: World Bank. 
You M. 2020. Changes of China's regulatory regime on commercial artificial breeding of terrestrial wildlife in time of COVID-19 outbreak and impacts on the future. Biological Conservation 250, 108576. https://doi. org/10.1016/j.biocon.2020.108756

Yiming L, Dianmo L. 1998. The dynamics of trade in live wildlife across the Guangxi border between China and Vietnam during 1993-1996 and its control strategies.
Biodiversity and Conservation 7: 895-914. https://doi. org/10.1023/A:1008873119651

Wilkie DS, Wieland M, Boulet $\mathrm{H}$, Le Bel S, van Vliet N, Cornelis $\mathrm{D}, \ldots$ and Fa JE. 2016. Eating and conserving bushmeat in Africa. African Journal of Ecology 54(4): 402-414.

Zhang L, Hua N and Sun S. 2008. Wildlife trade, consumption and conservation awareness in southwest China. Biodivers Conserv 17: 1493-1516. 